Удк 351

JEL classification: H00, H11, H19, H55, H77

\section{Дмитро ВОЙт}

кандидат економічних наук, докторант, Міжнародний університет бізнесу і права, Україна

E-mail: management@nuos.edu.ua ORCID: https://orcid.org/ 0000-0003-3406-2237

(c) Дмитро Войт, 2020

Отримано: 04.02.2020 p.

Прорецензовано: 17.02.2020 р.

Рекомендовано до друку: 26.02.2020 р.

Опубліковано: 28.02.2020 p.

\section{(c) (i) (S)}

Ця стаття розповсюджується на умовах ліцензії Creative Commons AttributionNonCommercial 4.0, яка дозволяє необмежене повторне використання, розповсюдження та відтворення на будь-якому носії, за умови правильного цитування оригінальної роботи.
Дмитро Войт (Україна)

\section{ФОРМУВАННЯ МЕХАНІЗМІВ ДЕЦЕНТРАЛІЗАЦІЇ СОЦІАЛЬНО- ЕКОНОМІЧНИХ ТЕРИТОРІАЛЬНИХ СИСТЕМ: РЕГІОНАЛЬНІ ОСОБЛИВОСТІ}

\section{АнотАцІя}

Вступ. Соціально-економічний регіональний розвиток базується на динамічній та збалансованій взаємодії двох сфер суспільного життя: соціальній та економічній. Економічна сфера життєдіяльності обумовлює виконання низки заходів, що спрямовані на покращення соціальної сфери: подолання бідності, забезпечення добробуту та комфортності життя, збереження здоров'я, забезпечення освіти, покращення умов праці тощо. Метою статті $\epsilon$ дослідження формування механізмів децентралізації соціально-економічних територіальних систем.

Метод (методологія). У досліджені застосовані загальнонаукові методи, зокрема теоретичного узагальнення - для узагальнення складових структури програмно-цільового підходу; системного економічного аналізу для обґрунтування механізму децентралізації соціально-економічних територіальних систем.

Результати. Запропонований механізм формування та розвитку децентралізованих соціально-економічних територіальних систем потребує подальшого удосконалення соціогуманітарних орієнтирів та державотворчого потенціалу національної самосвідомості у напрямку посилення гарантій системи соціального захисту та розвитку державноприватного партнерства. Головним орієнтиром модернізації стратегічних напрямів територіального та національного соціально-економічного розвитку має стати людино-центричний підхід, який передбачає першочергове врахування інтересів суб'єктів соціально-економічного розвитку.

Войт Д. Формування механізмів децентралізації соціально-економічних територіальних систем: регіональні особливості. Економічний аналіз. 2020. Том 30. № 1. Частина 2. С. 37-43.

DOI: https://doi.org/10.35774/econa2020.01.02.037

Ключові слова: механізм; регіональний розвиток; економічний розвиток; соціально-економічні територіальні системи 


\section{UDC 351}

JEL classification: H00, H11, H19, H55, H77

\section{Dmytro VOIT}

$\mathrm{PhD}$ in Economics,

Doctoral Student,

International University of Business and Law,

Ukraine

E-mail: management@nuos.edu.ua

ORCID: https://orcid.org/ 0000-0003-3406-2237

(C) Dmytro Voit, 2020

Received: 04.02.2020

Revised: 17.02 .2020

Accepted: 26.02.2020

Online publication date: 28.02 .2020

\section{(1) \$}

This is an Open Access article, distributed under the terms of the Creative Commons AttributionNonCommercial 4.0 license, which permits unrestricted re-use, distribution, and reproduction in any medium, provided the original work is properly cited.
Dmytro Voit (Ukraine)

\section{FORMATION OF MECHANISMS OF DECENTRALIZATION OF SOCIO- ECONOMIC TERRITORIAL SYSTEMS: REGIONAL FEATURES}

\section{ABSTRACT}

Introduction. Socio-economic regional development is based on dynamic and balanced interaction of two spheres of public life: social and economic. The economic sphere of life determines the implementation of a number of measures aimed at improving the social sphere: overcoming poverty, ensuring the wellbeing and comfort of life, maintaining health, providing education, improving working conditions and more.

The aim of the article is to study the formation of mechanisms for decentralization of socio-economic territorial systems.

Method (methodology). The general scientific methods, in particular theoretical generalization - for generalization of components of structure of the programtarget approach are applied in research; system economic analysis - to substantiate the mechanism of decentralization of socio-economic territorial systems.

Results. The proposed mechanism of formation and development of decentralized socio-economic territorial systems requires further improvement of socio-humanitarian guidelines and state-building potential of national selfconsciousness in the direction of strengthening the guarantees of social protection and public-private partnership. The main reference point for the modernization of strategic directions of territorial and national socio-economic development should be the human-centric approach, which provides for the priority consideration of the interests of the subjects of socio-economic development.

Voit, D. (2020). Formation of mechanisms of decentralization of socio-economic territorial systems: regional features. Economic analysis, 30 (1, Part 2), 37-43.

DOI: https://doi.org/10.35774/econa2020.01.02.037

Keywords: mechanism; regional development; economic development; socioeconomic territorial systems.

\section{Вступ}

Соціально-економічний регіональний розвиток базується на динамічній та збалансованій взаємодії двох сфер суспільного життя: соціальній та економічній. Економічна сфера життєдіяльності обумовлює виконання низки заходів, що спрямовані на покращення соціальної сфери: подолання бідності, забезпечення добробуту та комфортності життя, збереження здоров'я, забезпечення освіти, покращення умов праці тощо.

Водночас, у зв'язку з євроінтеграційними процесами, у напрямку формування регіональної політики розвитку набуває актуальності сталий розвиток територіальних систем, який виступає основою європейської політики соціально-економічного територіального розвитку.

Питання формування механізмів децентралізації соціальноекономічних територіальних систем попередньо досліджували відомі 
www.econa.org.ua

учені України, зокрема: О. Бутнік-Сіверський, Г. Гузенко, В.Гунько, Ю. Ґава, І. Іртищевою, І. Крамаренко, Е. Лібанова, А. Никифоров, М. Стегней, В. Семикіна та ін. В сучасних умовах реформування постає питання щодо поглиблення вивчення функціонування сучасних інституцій регіонального економічного розвитку в умовах соціалізації.

\section{Мета дослідження}

Метою статті $\epsilon$ дослідження формування механізмів децентралізації соціально-економічних територіальних систем.

\section{Виклад основного матеріалу}

Концепція сталого розвитку лягає в основу європейського регіонального розвитку на засадах демократичного місцевого або територіального управління. На рівні територіальних громад важливо дотримуватися принципів сталого розвитку, особливо у випадку довгострокового планування необхідно зберігати відповідальність перед інтересами майбутніх поколінь, а саме: теперішні рішення не повинні зашкодити сталому розвитку майбутніх поколінь, а повинні враховувати всі еколого-соціально-економічні ризики та перспективи і забезпечувати подальший успішний розвиток громади та суспільства. Необхідно також намагатися зберегти історичні, культурні, природні цінності й традиції.

Концепція сталого розвитку базується на п'яти принципах (рис. 1).

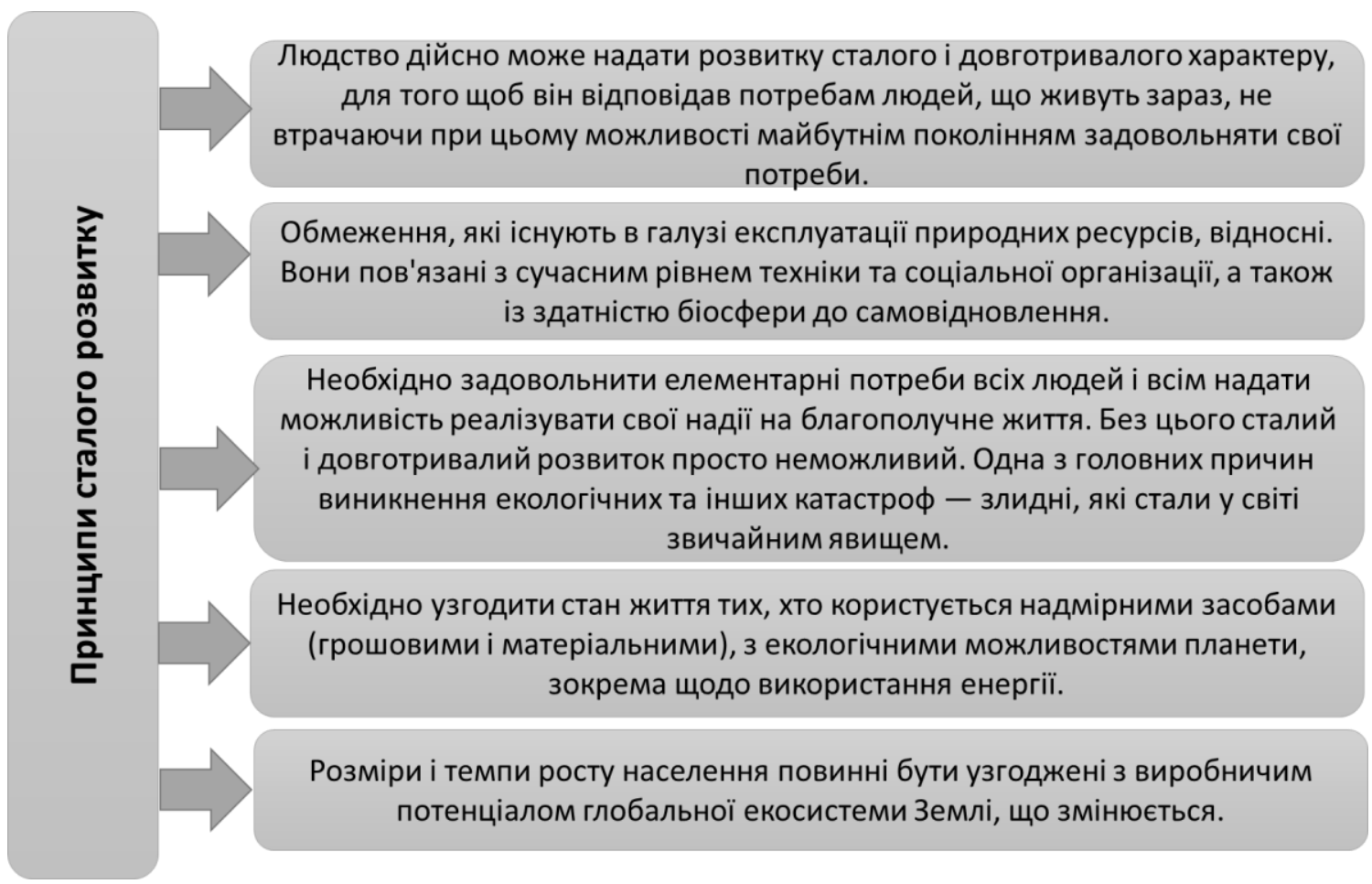

Рис. 1. Принцип сталого розвитку

Джерело: [1].

Пріоритетами у розвитку територіальних систем повинні бути забезпечення зайнятості населення, медичного обслуговування, продовольчої безпеки, освіти та культури, комунально-житлового обслуговування, збалансованого природокористування та безпечного довкілля. Розширений перелік послуг та соціальних гарантій населення визначається органами державного управління та самоврядування на рівні територіальних громад, що координується державною системою регулюючих нормативних актів. На сьогоднішньому етапі реформування важливим $€$ формування виробничих комплексів, кластерних структур та розвиток державноприватного партнерства за участі держави, бізнесу і громади.

Програмно-цільовий метод та системний підхід дають можливість забезпечити взаємозв'язок національних, галузевих, регіональних та територіальних програм розвитку. ПЦМ є основою планомірного збалансованого сталого розвитку національної економіки та територіальних економічних систем. 
www.econa.org.ua

ПЦМ вважають системним циклічним підходом вирішення завдань, початок та завершення якого повинен ідентифікуватися послідовністю соціальноекономічних проблем, що підлягають вирішенню. Кожен окремий цикл повинен поєднуватися із оцінкою індикаторів ефективності та ступеня досягнення цілі. Кожна програма повинна ідентифікуватися системою контрольних показників iï виконання, що мають чітко відповідати поставленій меті (цілі). Доцільним вважається формування програм із конкретними чітко визначеними ціллю та завданнями, кількість яких має бути не великою, обмеженою. Такі програми легше виконувати та моніторити [2].

Особливістю програмно-цільового методу $\epsilon$ намагання охопити максимальну кількість послуг у розрахунку на одиницю витрат. Бюджет повинен враховувати обсяг робіт та кошти на їх виконання. Традиційне бюджетування передбачає необхідність контролю за цільовим використанням коштів, а програмно-цільовий підхід передбачає можливість поетапного фіскального контролю результатів виконання програми. ПЦМ передбачає конкретизацію кількісних показників, часових орієнтирів та якісних оцінок [3, с. 13].

Таким чином, застосування програмно-цільових підходів на рівні управління територіальними системами використовуються єдині методичні підходи, що передбачають обґрунтування елементів ієрархічної структури (функції, напрями діяльності, деталізований підхід, складові елементи), формулювання мети, завдань та визначення індикаторів результативності (рис. 2). Мета (ціль) діяльності передбачає лаконічне обґрунтування функцій, які мають бути узгоджені із національними та регіональними стратегіями розвитку, враховувати специфіку територіальної системи. Основою для розробки територіальних програм розвитку має бути обґрунтування очікуваних результатів, спрямованих на соціальнозначущі результати та покращення життєдіяльності територіальної громади.

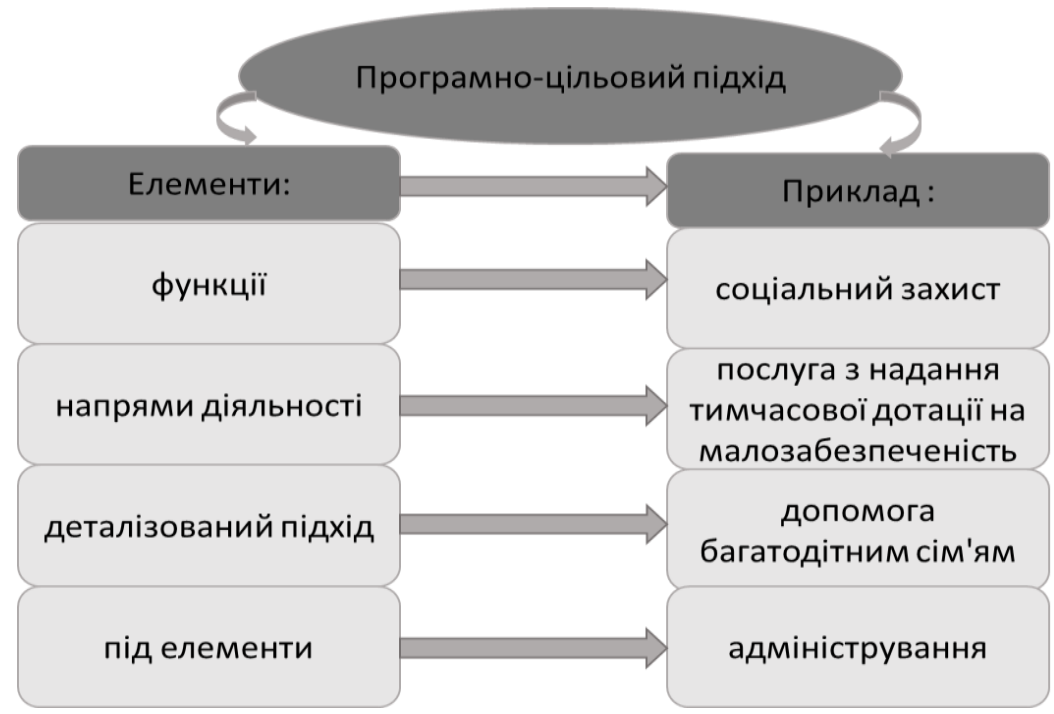

Рис. 2. Ієрархічна структура програмно-цільового підходу

Джерело: узагальнено на підставі [3].

Системний підхід отримав своє застосування в різних програмах та стратегіях розвитку. 3 практичної точки зору, під ним розуміють комплексний розвиток на підставі використання потенційних можливостей. Таке розуміння звужує можливість його застосування у процесі планування розвитку територіальних систем, адже намагання досягти ефективного розвитку в усіх сферах і галузях протирічить можливості зосередитися на пріоритетних напрямах розвитку, реалізація якої дала поштовх до позитивних зрушень в інших сферах або галузях. Саме тому важливим $\epsilon$ розумне поєднання системного i ситуативного підходів в моделях розвитку територіальних систем.
Моделі створення територіальних об'єднаних громад базуються саме на ситуативному підході, який враховує поєднання найбільш вигідних для окремої територіальної системи варіантів об'єднання, з урахуванням факторів соціальноекономічного становища, у відповідності до конкретної ситуації. В умовах самоврядування на місцевому рівні часто застосовується саме ситуативний підхід для вирішення окремих проблемних питань територіальної громади 3 певними (ситуативними) ресурсами.

В межах ситуативного підходу розрізняють модель «щрозвиток територіальних громад на основі місцевих ресурсів", яка передбачає актуалізацію сильних сторін, використання наявних ресурсів та потенціалу. Територіальна громада стає 
www.econa.org.ua

активним організатором своєї життєдіяльності і відходить від режиму очікування дотацій, субвенцій та іншої підтримки з боку регіону та держави. Дослідник В. Карпенко зауважує, що ситуативний підхід є ефективним тільки за умови розвитку між секторального партнерства [4].

Щодо формування економічної сфери розвитку територіальних систем, то виділяють або розрізняють ліберальний підхід, котрий визначає першочерговість розвитку бізнесу, та прогресивний підхід, котрий визначає першочерговість розвитку потенціалу територіальної громади. Ліберальні засади економічної сфери розвитку територіальних систем передбачають забезпечення зайнятості населення за рахунок інвестицій у розвиток малого та середнього бізнесу. Прогресивні засади економічної сфери розвитку територіальних систем передбачають поширення нетрадиційних форм організації трудової діяльності (кооперативи, громадські об'єднання тощо), що дає можливість розвитку державно-приватного партнерства на шляху досягнення цілей, які об'єднують інтереси громади, бізнесу, влади та самоврядування [5].

Популярний сьогодні кластерний підхід також стосується формування економічної сфери розвитку територіальних систем. Кластерний підхід дозволяє територіальним громадам використовувати власний потенціал та використовувати переваги територіального розміщення і сусідства із іншими територіальними системами. Кластерний підхід розширює коло постачальників та споживачів, розширює можливості використання людських ресурсів, розширює можливості інформаційного обміну, що дає можливість збільшувати ефективність та результативність економічної сфери розвитку територіальних систем [6].

Поєднання всіх попередньо згаданих підходів формування соціально-економічної сфери розвитку територіальних систем характеризується інтеграційним підходом, який дає можливість на різних етапах та в різних ситуаціях обирати пріоритетні шляхи досягнення цілей та вирішення завдань. Інтегроване використання різних підходів формування економічної сфери розвитку територіальних систем дає можливість використовувати специфіку територіальних систем на благоустрій громади, добробут населення та благо майбутніх поколінь.

На підставі аналізу існуючих підходів формування та розвитку територіальних систем нами виділено основні складові децентралізованої соціально-економічної територіальної системи через сукупність механізмів планування розвитку, основоположних принципів програм та проектів розвитку територіальних систем, стратегічних завдань та цілей (рис. 2).

$\begin{array}{rrr}\text { Механізм формування та розвитку } \\ \text { децентралізованих } \\ \text { територіальних } & \text { соціально-економічних } \\ \text { систем } & \text { можливо }\end{array}$

охарактеризувати як взаємо узгоджену систему нормативно-правового та методичного забезпечення, що базується на засадах використання основоположних принципів розвитку територіальних систем (сталість, багаторівневість, партнерство, динамічність, орієнтованість на потреби місцевого населення, співучасть громадськості) та спрямована на забезпечення благоустрою громади, добробут мешканців та благо майбутніх поколінь та на підвищення конкурентоспроможності територіальної системи (рис. 3).

Серед переліку методичного забезпечення механізму формування та розвитку децентралізованих соціально-економічних територіальних систем важлива роль належить програмно-цільовому методу орієнтованому на результативність використання ресурсів на основі системного підходу та методу розвитку територіальних громад з використанням місцевих ресурсів на основі ситуативного підходу, а також методиці формування спроможних громад.

Запропонований механізм формування та розвитку децентралізованих соціальноекономічних територіальних систем потребує удосконалення соціогуманітарних орієнтирів та державотворчого потенціалу національної самосвідомості у напрямку посилення гарантій системи соціального захисту та розвитку державноприватного партнерства.

\section{Висновки та перспективи подальших розвідок}

Визначено механізм формування та розвитку децентралізованих соціально-економічних територіальних систем як взаємо узгоджену систему нормативно-правового та методичного забезпечення, що базується на засадах використання основоположних принципів розвитку територіальних систем (сталість, багаторівневість, партнерство, динамічність, орієнтованість на потреби місцевого населення, співучасть громадськості) та спрямована на забезпечення благоустрою громади, добробут мешканців та благо майбутніх поколінь та на підвищення конкурентоспроможності територіальних систем. Серед переліку методичного забезпечення механізму формування та розвитку децентралізованих соціально-економічних територіальних систем важлива роль належить програмно-цільовому методу орієнтованому на результативність використання ресурсів на основі системного підходу та методу розвитку територіальних громад з використанням місцевих ресурсів на основі ситуативного підходу, а також методиці формування спроможних громад. 


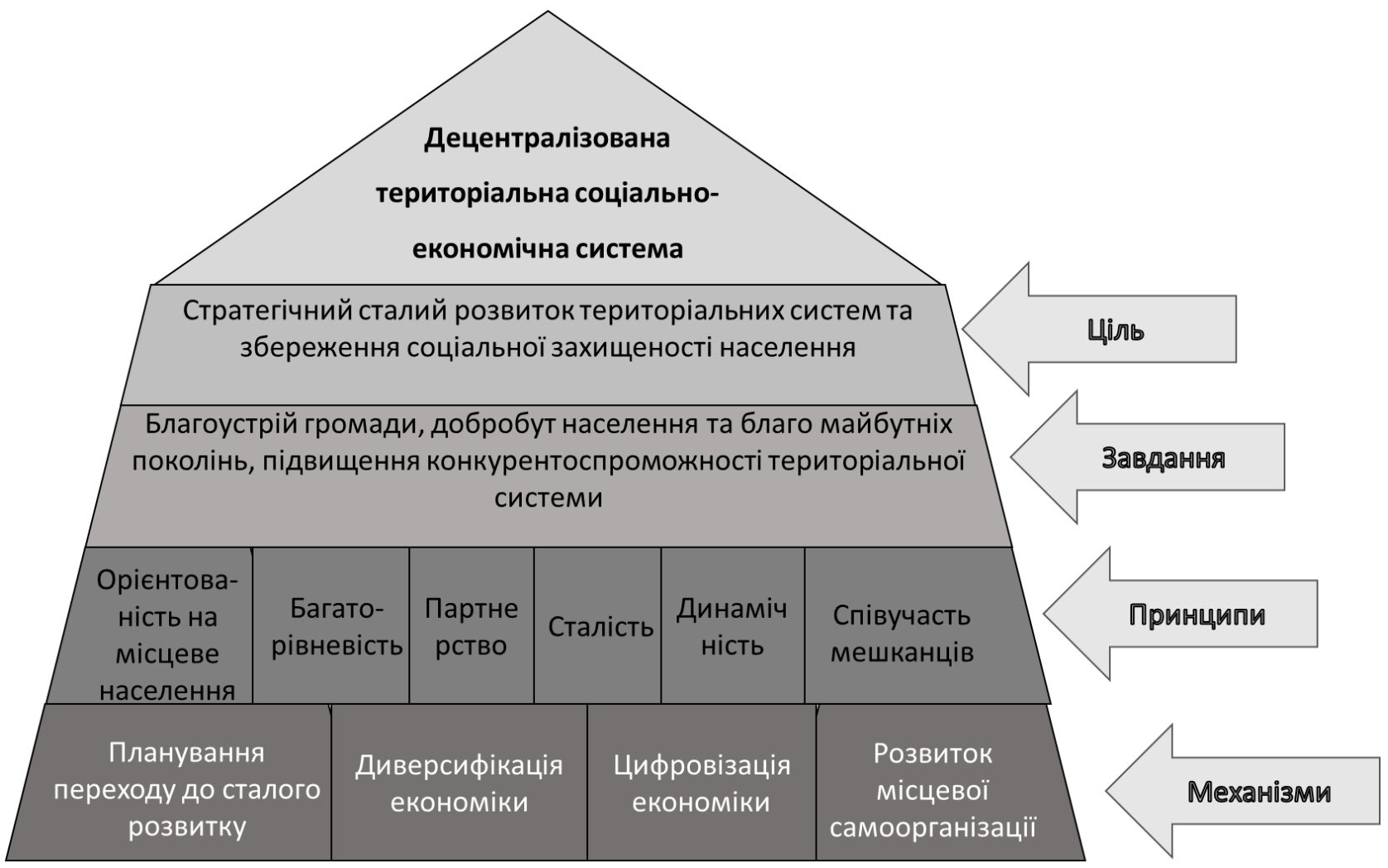

Рис. 2. Методологічна піраміда формування та розвитку децентралізованої соціально-економічної територіальної системи

Джерело: авторська розробка.

\section{Механізм формування та розвитку децентралізованих соціально-економічних територіальних систем

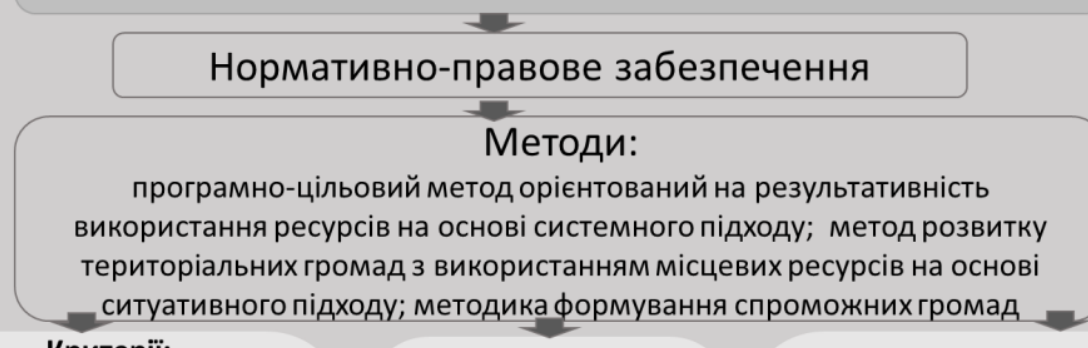 \\ Критерії:}

1.Чисельність постійного населення;

2.Чисельність учнів;

3.Площа території;

4.Індекс

податкоспроможності;

5.Частка місцевих податків та зборів у доходах бюджету спроможної територіальної громади.

\section{Принципи:}

1.Сталість

2.Багаторівневість;

3.Партнерство;

4.Динамічність;

5.Орієнтованість на

місцеве населення;

6.Співучасть

громадськості.
Завдання:

1.Забезпечення

благоустрою громади;

2. Добробут мешканців;

3. Благо майбутніхпоколінь;

4.Підвищення

конкурентоспроможності

територіальної системи.

Рис. 3. Механізм формування та розвитку децентралізованих соціально-економічних територіальних систем

Джерело: авторська розробка . 
www.econa.org.ua

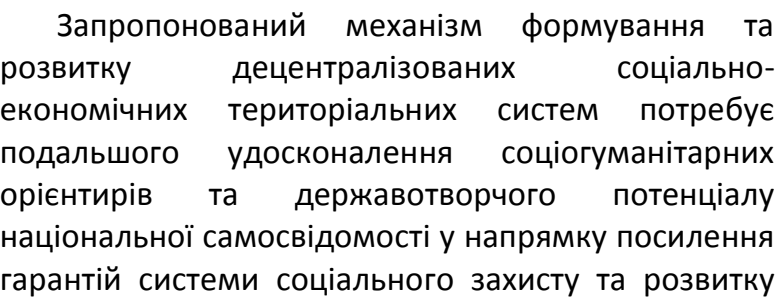

державно-приватного партнерства. Головним орієнтиром модернізації стратегічних напрямів територіального та національного соціальноекономічного розвитку має стати людиноцентричний підхід, який передбачає першочергове врахування інтересів суб'єктів соціальноекономічного розвитку.

\section{СПИСОК ВИКОРИСТАНИХ ДЖЕРЕЛ}

1. Сталий розвиток. Вікіпедія. URL https://uk.wikipedia.org/wiki/Стали й_розвиток.

2. Грішнова О. А. Зарубіжний досвід фінансування освіти та перспективи його застосування в Україні. Наукові праці НДФІ. 2000.

3. Планування місцевих бюджетів на методу: Навчальний посібник [під заг. ред., В. В. Зубенко] ; ІБСЕД, Проект «Зміцнення місцевої фінансової ініціативи (ЗМФІ-ІІ) впровадження» [4-те вид., вип. та допов.]. Київ., 2013. $120 \mathrm{c}$ Вип. 10-11. С. 214-222. основі програмно-цільового

4. Карпенко В. В. Міжсекторне партнерство в процесі розвитку громад: світовий досвід. Теоретичні та прикладні питання державотворення: електрон. наук. фах. вид. 2008. № 3. URL: http://www.nbuv.gov.ua/ejournals/tppd/2011_8/zmist/ R_2/07Karpenko.pdf.

5. Ільченко Н., Жиленко Р. Економічний розвиток громади: контекст та практика (досвід Канади). Економічний розвиток громади. 2006. № 2. С. 35-40.

6. Чикаренко І. Кластерний підхід в управлінні економічним розвитком муніципального утворення. Державне управління та місцеве самоврядування : зб. наук. праць. 2010. Вип. 4 (7). URL: http://www.nbuv.gov.ua/portal/Soc _Gum/Dums/2010_4/10ciarmu.pdf.

\section{REFERENCES}

1. Sustainable development Wikipedia. Retrieved from: https://en.wikipedia.org/wiki/Stall_ Development [in Ukrainian].

2. Grishnova, O. A. (2000). Foreign experience in financing education and prospects for its application in Ukraine, Scientific works of NDFI, vol. 10-11, pp. 214-222. [in Ukrainian].

3. Planning of local budgets on the basis of the program-target method (2013). Kiev: IBSED, Project "Strengthening Local Financial Initiative (ZMFI-II) Implementation" [in Ukrainian].
7. Irtyshcheva I., Kramarenko I., Shults S., Boiko Y., Blishchuk K., Hryshyna N., Popadynets N., Dubynska I., Ishchenko O., Krapyvina D. Building favorable investment climate for economic development. Accounting. 2020. Volume 6 . Number 5. Pp. 773-780.

8. Іртищева І. О., Стройко Т. В. Стегней М. І. Неприбутков організації в системі світових соціально-економічних процесів: монографія. Херсон: Гельветинка, 2013. 250 c.

9. Іртищева І. О., Крамаренко І. С Інвестиційна привабливість економіки: міжрегіональні асиметрії. Регіональна економіка. 2014. № 2 (72). С. 84-95.
4. Karpenko, V. V. (2008) Crosssectoral partnership in the process of community development: world experience. Theoretical and applied issues of state formation: electron. Science. profession. kind. no. 3. Retrieved from: http://www.nbuv.gov.ua/ejournals/tppd/2011_8/zmist/R_2/07 Karpenko.pdf. [in Ukrainian].

5. Ilchenko, N. and Zhilenko, R. (2006). Economic development of the community: context and practice (Canadian experience), Economic development of the community, no. 2, pp. 35-40. [in Ukrainian].

6. Chikarenko, I. (2010). Cluster approach in managing the economic development of the municipality, Public administration and local selfgovernment: coll. Science. wash, 4 (7). Retrieved from: http://www.nbuv.gov.ua/portal/Soc Gum/Dums/2010_4/10ciarmu.pdf. [in Ukrainian].
7. Irtyshcheva, I., Kramarenko, I. Shults, S., Boiko, Y., Blishchuk, K., Hryshyna, N., Popadynets, N., Dubynska, I., Ishchenko, O. and Krapyvina, D. (2020). Building favorable investment climate for economic development, Accounting, 6(5), 773-780.

8. Irtyshcheva, I. O., Stroyko, T. V. and Stegney, M. I. (2013). Non-profit organizations in the system of world socio-economic processes, Kherson: Helvetinka, Ukraine. [in Ukrainian].

9. Irtyshcheva, I. O. \& Kramarenko, I. S. (2014). Investment attractiveness of the economy: interregional asymmetries, Regional economy, 2 (72), 84-95. [in Ukrainian]. 